\title{
Endophytic Mycoflora of Indian Medicinal Plant, Terminalia arjuna and their Biological Activities
}

\author{
M.P. Patil ${ }^{1}$, R.H. Patil ${ }^{1}$, S.G. Patil ${ }^{1}$ and V.L. Maheshwari ${ }^{2, *}$ \\ ${ }^{1}$ Department of Microbiology and Biotechnology, R.C. Patel Arts, Commerce and Science College, Shirpur \\ 425405 (MS), India \\ ${ }^{2}$ Department of Biochemistry, School of Life sciences, North Maharashatra University, Jalgaon 425001 (MS), \\ India
}

\begin{abstract}
Studies were undertaken to isolate, identify and evaluate the biological activities of endophytic mycoflora of Indian medicinal plant, Terminalia arjuna. A total of 20 isolates of endophytic fungi were obtained from the leaves, twigs and bark tissues of the Terminalia arjuna. Out of 20 , six isolates exhibited promising antibacterial, antifungal and antiinflammatory activities when cultivated at shake flask level. The selected isolates were identified on the basis of morphology and ITS gene sequencing. Three isolates, designated as TA BA 1, TA L1 and TA L2 were identified as Aspergillus flavus whereas; the remaining three endophytic fungi were identified as Diaporthe arengae (TA TW2), Alternaria Sp. (TA TW1) and Lasiodiplodia theobromae (TA BA2). Aspergillus flavus was found as the predominant endophyte in leaves and bark tissues of the plant. The crude extract of the test isolates showed considerable antimicrobial activity against common human bacterial (Staphylococcus aureus, Escherichia coli, Pseudomonas aeruginosa, Proteus vulgaris, Salmonella abony and Bacillus subtilis) and fungal (Candida albicans, Aspergillus niger and Penicilium sp.) pathogens. The extract of Diaporthe arengae (TA TW2) significantly reduced the concentration of DPPH free radical as percent DPPH scavenging activity was found to be highest $(69.56 \%)$ in comparison with other isolates. The \% inhibition of hemolysis of RBCs was found to be highest (82.85\%) with Diaporthe arengae (TA TW2) in comparison (83.26\%) with standard drug (Ibuprofen). Among all, the extract of the Diaporthe arengae (TA TW2) showed excellent biological activities and hence was subjected to further characterization. The phytochemical investigation of the extract revealed the presence of terpenoids as the major phytoconstituents which was supported by TLC and UV spectroscopic studies. The results indicate that the isolated endophytes could be the valuable source of these bioactive molecules with diverse biological activities. The bioactivities may be attributed to the terpenoids present in the endophytic extract.
\end{abstract}

Keywords: Endophytic fungi, Aspergillus flavus, anti-inflammatory, ITS, terpenoids, antimicrobial activity.

\section{INTRODUCTION}

The need of safe and economically affordable bioactive molecules is ever-increasing. The plants, animals and microorganisms have been the economical and important sources of these biologically important compounds. Metabolites synthesized by these organisms are the result of millions of years of evolution and natural selection. Microorganisms, the most preferred source of bioactive compounds, are generally obtained from the soil. However, $80 \%$ of world's soil has been screened out for new potential isolates for bioactive molecules. Secondly, only $1 \%$ of soil microflora is cultivable which can be used as a source of bioactive molecules [1]. Therefore, there is an urgent need to find alternate sources and strategies for the search of novel and safe bioactive molecules.

Endophytes are the "microbes that colonize living, internal tissues of plants without causing any immediate, over negative effects" [1]. Almost every plant possesses one or other type of an endophytic

*Address correspondence to this author at the Department of Biochemistry, School of Life sciences, North Maharashatra University, Jalgaon 425001 (MS), India; Fax: 0912572258403; E-mail: vlmaheshwari@rediffmail.com bacteria and/or fungi. However, the most frequently isolated endophytes are the fungi [2]. Since, most of the endophytes establish symbiotic relationship with their host, they do not cause any harm to their host plant. Despite of their huge biological potential and promise for novel chemistry, endophytes of the many Indian medicinal plants are relatively understudied. It has been hypothesized that these plants harbor some distinct and rare microbes that could mimic the chemistry of their host plant [3, 4]. Fungal endophytes are known to produce bioactive molecules like flavonoids [5], taxol and terpenoids [6] and various enzymes like asparginase [7]. Paclitaxel (Taxol), a natural bioactive diterpene derivative and a widely used anticancer drug, was first identified from the Pacific yew Taxus brevifolia [8]. Gond et al. [9] have isolated and characterized a total of 79 endophytic fungi belonging to 21 genera from Aegle marmelos. Bartaliniarobillardoides, a coelomycetous fungus, isolated as an endophyte from the leaves of Aegle marmelos was shown to produce the taxol [10].

Terminalia arjuna, an indigenous medicinal plant, commonly known as Arjuna is a large deciduous tree found all over India and Himalaya [11]. The bark of $T$. 
arjuna has been recommended and used as cardiac tonic and bark powder/decoction is used to treat heart diseases, bone fractures, skin diseases, polyuria, hypercholesterolemia, white discharge, giddiness, fever and worms $[12,13]$. In the present study, various aerial parts of $T$. arjuna were investigated for the presence of endophytes. The isolated fungal endophytes were characterized morphologically as well as by ITS gene sequencing and cultivated at shake flask level. Further, various biological activities of the fermentation extract were evaluated. Attempts were also made to partially characterize the bioactive metabolite(s) present in the broth culture using TLC and UV spectroscopy.

\section{MATERIALS AND METHODS}

\section{Isolation of Endophytic Fungi}

Fresh and healthy leaves, twigs and bark of the Terminalia arjuna were collected from the medicinal plant garden of R.C. Patel Pharmacy College, Shirpur (MS, India) and authenticated by an expert taxonomist and a voucher specimen was deposited in the College. The plant material was thoroughly washed under tap water and disinfected using $0.5 \%$ sodium hypochlorite (2min) and air dried in laminar flow hood [14]. The outer tissues of the selected plant parts were carefully removed with sterile scalpel so as to expose the inner tissues and were cut into $1.5 \times 1.5 \mathrm{~cm}$ pieces. The cut tissues were aseptically placed on the surface of Petri plate containing sterile water agar. In order to avoid bacterial contamination, chloramphenicol was added $(400 \mu \mathrm{g} / \mathrm{ml}$, after sterilization). The plates were incubated at $25^{\circ} \mathrm{C}$ for 12 hours dark and light cycle until fungal hyphae appeared. After emergence of sufficient number of hyphae, the isolate was sub-cultured on fresh Czapek Dox agar slant in order to obtain the pure culture. All the isolated fungi were maintained on Czapek Dox agar slants at $4^{\circ} \mathrm{C}$.

\section{Morphological and Molecular Identification of Isolated Endophytes}

The morphological identification of the fungi was done as per the methods of Raper and Fennel, [15]. For molecular identification, the total genomic DNA of the isolates was prepared as per the previously reported method [16]. The fungal 18s rDNA gene was PCR amplified from the total chromosomal DNA using universal eubacteria specific primer ITS1 and ITS4. The ITS sequences obtained above were aligned by using BLAST analysis at NCBI server (http://www.ncbi. nlm.nih.gov/BLAST). The sequence was submitted to
GenBank and the accession numbers were obtained for all six isolates. For comparison with currently available sequences, sequences over $98.5 \%$ similarities from the same genera were retrieved from the NCBI database and multiple sequence alignment was performed by using ClustalX 2.0. Non informative sites were deleted using DAMBE 5.1.1. Phylogenetic tree was constructed using software mega4.

\section{Laboratory Cultivation of Fungal Endophytes}

All six isolates were cultivated in liquid culture in order to check their ability to produce bioactive metabolites. A spore suspension was obtained from the master plate by scrubbing the plate with $5 \mathrm{ml}$ of sterile aqueous solution of $2 \%$ tween 80 . Inoculum was developed by inoculating $5 \mathrm{ml}$ spore suspension in 250 $\mathrm{ml}$ Erlenmeyer flask containing ( $\mathrm{g} / \mathrm{l})$ : lactose, 60; soybean meal, $25 ; \mathrm{KH}_{2} \mathrm{PO}_{4}, 2 ; \mathrm{K}_{2} \mathrm{HPO}_{4}, 1 ; \mathrm{MgSO}_{4} .7 \mathrm{H}_{2} \mathrm{O}$, $0.5 ; \mathrm{FeSO}_{4} .4 \mathrm{H}_{2} \mathrm{O}, 1 ; \mathrm{NaNO}_{3}, 0.5 ; \mathrm{MnSO}_{4} .7 \mathrm{H}_{2} \mathrm{O}, 0.5$. After developing sufficient biomass, $10 \%$ of inoculum was transferred to production medium of same composition. The $\mathrm{pH}$ of the medium was maintained at 5.5 (after sterilization). All fermentations were carried out at $28^{\circ} \mathrm{C}$ and $150 \mathrm{rpm}$ for 16 days on rotary shaker (Steelmate Novatech, CV-10, Pune, India) in $500 \mathrm{ml}$ shake flask containing $150 \mathrm{ml}$ of production medium.

\section{Recovery and Extraction of Bioactive Principle}

At the end of incubation, fermented broth was filtered with muslin cloth to separate the mycelia. The resulting culture filtrate was extracted with ethyl acetate and the solvent phase was reduced under pressure using rotary vacuum evaporator (Roteva, Equitron, Mumbai, India). Residue was re-dissolved in methanol and used for further analysis [14]. The resulting crude extract was subjected to various tests for the qualitative determination of different bioactive secondary metabolites present in the extract [17].

\section{Antimicrobial Assay}

The test pathogens were obtained from National Collection of Industrial Microorganisms (NCIM), Pune, India. The panel of test pathogens selected for the study included both Gram negative [Escherichia coli (NCIM 2065), Pseudomonas aeruginosa (NCIM 2200), Salmonella abony (NCIM2257) and Proteus vulgaris (NCIM 2027)] as well as Gram positive [Bacillus subtilis (NCIM 2063) and Staphylococcus aureus (NCIM 2079)] microorganisms. The assay was carried out using agar well diffusion method. A suspension of the test bacterial pathogen of $0.1 \mathrm{ml}$ in concentration of $\left(10^{6}\right.$ 
cells/ml) was uniformly spread on the agar layer using sterile swab. The antifungal activity was carried out using Candida albicans (NCIM 3471), Aspergillus terreus (NCIM 657), Aspergillus niger (NCIM 1196) and Penicillium Spp. (NCIM 763) Spore suspension of the test pathogen of $0.1 \mathrm{ml}$ in concentration of $\left(7 \times 10^{2}\right.$ spores $\left./ \mathrm{ml}\right)$ was swabbed on sterile Czapek Dox agar plates. Wells were prepared using sterile $7 \mathrm{~mm}$ cork borer and $0.5 \mathrm{ml}$ of crude extract was loaded in them. Streptomycin $(100 \mu \mathrm{g} / \mathrm{ml})$ and Flucanazole $(100 \mu \mathrm{g} / \mathrm{ml})$ were served as positive control for bacteria and fungi, respectively; whereas solvent ethyl acetate served as negative control. Plates were kept in refrigerator for 15 minutes for diffusion and then shifted to an incubator. After incubation $\left(24 \mathrm{~h}\right.$ at $37{ }^{\circ} \mathrm{C}$ for bacteria and $36 \mathrm{~h}$ at $30^{\circ} \mathrm{C}$ for fungi), the plates were observed and zones of inhibition were recorded.

\section{DPPH Radical Scavenging Activity}

The free radical scavenging activity of extract was determined by using 1, 1 diphenyl 2 picryl-hydrazyl (DPPH) [18]. Briefly, $1000 \mu l$ crude extract was mixed with $0.2 \mathrm{mM}$ methanolic solution $(1 \mathrm{ml})$ containing 1,1 diphenyl 2 picryl-hydrazyl (DPPH). The mixture was shaken vigorously and left to stand for $30 \mathrm{~min}$ in the dark, and the absorbance was measured at $517 \mathrm{~nm}$ against a blank. The scavenging activity of DPPH radical was calculated using the following equation:

DPPH scavenging effect $(\%)=\left[\left(A_{0}-A_{1} / A_{\circ}\right) \times 100\right]$

Where, $A_{0}$ was the absorbance of the control reaction and $A_{1}$ the absorbance in the presence of the sample.

\section{Hydroxy Radical Scavenging Activity}

Hydroxy radical scavenging activity was measured by the salicylic acid method [19] with modifications. Reaction mixture $(3.0 \mathrm{ml})$ contained $1.0 \mathrm{ml}$ of $1.5 \mathrm{mM}$ $\mathrm{FeSo}_{4}, 0.7 \mathrm{ml} 6 \mathrm{mM} \mathrm{H}_{2} \mathrm{O}_{2}, 0.3 \mathrm{ml}$ of $20 \mathrm{mM}$ sodium salicylate and varying concentrations $(0.2-1.0 \mathrm{mg} / \mathrm{ml})$ of the crude extract. After incubation at $37^{\circ} \mathrm{C}$ for $60 \mathrm{~min}$, the absence of the hydroxylated salicylate complex was measured spectrophotometrically (Schimadzu 1750 , Japan) at $562 \mathrm{~nm}$. The percent scavenging effect was calculated as

Scavenging activity $=\left\{1-\left[T_{1}-T_{2}\right] / T_{0}\right\} \times 100$

Where, $T_{1}$ was absorbance of the crude extract, $T_{2}$ was the absorbance without sodium salicylate and $T_{0}$ 。 was absorbance of the control (without extract).

\section{Anti-Inflammatory Activity}

Fresh human blood sample were collected into an anticoagulant $(0.8 \%$ sodium citrate, $0.05 \%$ citric acid and $0.42 \% \mathrm{NaCl}$ ) solution and centrifuged at $3000 \mathrm{rpm}$ for $10 \mathrm{~min}$ at room temperature. The upper layer was carefully removed and packed red blood cells were washed in normal saline $(0.85 \% \mathrm{w} / \mathrm{v} \mathrm{NaCl})$. Hematocrit $(2 \% \mathrm{v} / \mathrm{v})$ was prepared and used for membrane stabilization assay as reported previously [20]. The assay mixture contained $2 \mathrm{ml}$ of hyposaline $(0.25 \% \mathrm{w} / \mathrm{v}$ $\mathrm{NaCl}), 1.0 \mathrm{ml}$ of $0.15 \mathrm{M}$ sodium phosphate buffer $(\mathrm{pH}$ $7.4), 0.5 \mathrm{ml}$ of $2 \%$ human hematocrit suspension, $0.2-1.0 \mathrm{mg} / \mathrm{ml}$ of drug/extract and final volume was made up to $4.5 \mathrm{ml}$ with isosaline [20]. Standard drug, Ibuprofen $(1 \mathrm{mg} / \mathrm{ml})$ was prepared in isosaline to a final concentration $0.2-1.0 \mathrm{mg} / \mathrm{ml}$. Drug was omitted in the blood control, while the drug control did not contain the erythrocyte suspension. The reaction mixtures were incubated at $56^{\circ} \mathrm{C}$ for $30 \mathrm{~min}$ in a water bath, followed by centrifugation at $5000 \mathrm{rpm}$ for $10 \mathrm{~min}$ at room temperature. The absorbance of the released hemoglobin was read at $560 \mathrm{~nm}$. The percent hemolysis was calculated using the formula:

$\%$ hemolysis $=(O D$ of test $/ O D$ of control $\times 100)$

Each test was carried out in three replicates.

\section{Chromatographic and Spectroscopic Characterization of Diaporthe arengae (TA TW2) Extract}

The fermentation broth of the isolate Diaporthe arengae (TA TW2) showing best bioactivities was subjected for chromatographic and spectroscopic characterization. Preparatory thin layer chromatography (PTLC) was carried out on $5 \times 10 \mathrm{~cm}$ glass plates uniformly coated with Silica gel- G-60 for qualitative determination of metabolites present in the broth extract. Test sample, ethyl acetate extract of the fermented broth, was applied on TLC plate (Three bands with 10, 20 and $30 \mu$ l concentration) using automatic sample applicator (Spraylin, Aetron, Mumbai, India) and air dried. The plate development was carried out using different mobile phases (Dichloromethane: Ethyl acetate, 7:3; Chloroform: Ethanol, 1:1; Benzene: Acetonitrile, 5:5 and chloroform: ethyl acteate, 7:3 v/v)

After separation, plates were observed under UV light and after derivatization; with $5 \% \mathrm{H}_{2} \mathrm{SO}_{4}$ in visible light and $R_{f}$ value of the major band was calculated. The well resolved band at $R_{f}-0.42$ showing greenish fluorescence was cut with a sharp knife, scrapped and 
re-dissolved in ethyl acetate. The resulting sample was filtered and centrifuged. The purified sample was redissolved in ethyl acetate and spectrum was recorded between 200-700nm by UV-Visible spectrophotometer (Shimadzu 1750, Japan).

\section{RESULTS AND DISCUSSION}

\section{Isolation and Identification of Endophytic Fungi}

A total of twenty endophytic fungi were isolated in the pure culture from the leaves, twigs and the bark tissues of the Terminalia arjuna. Based on screening studies on their bioactivities, six isolates were selected and subjected for morphological and molecular identification. All six short listed endophytic fungal isolates could be cultivated on Czapek Dox agar and maintained as pure cultures. They exhibited characteristic colony and microscopic morphology that could be used to differentiate them (Figure 1). According to the results of molecular identification, the plant was dominantly colonized by the Aspergillus Spp. (Figure 2). In bark and leaves, Aspergillus and Lasiodiplodia were dominating genera present. Diaporthe Spp. followed by Alternaria Spp. were dominant in the twigs tissue of the plant. The isolate TATW2, the most promising isolate in the study, showed $100 \%$ similarity with Diaporthe arengae. Another isolate, TA L1 formed subgroup with Aspergillus flavus. The Endophytes colonizing inside plant tissues usually get nutrition and protection from the host plant and, in response, they produce some functional metabolites, which enhance the host fitness, resistance against stresses as well as quality of the products [21].

\section{Antimicrobial Activity}

The antibacterial and antifungal activities of fermentation extract of six endophytic fungi and their comparison with reference drugs is showed in Table 1. Among six bacterial pathogens tested, E. coli, $S$. aureus and $B$. subtilis were found to be sensitive to extract of all the endophytic fungi except TA L2 and TA BA 1 (Figure 3). The extract of Diaporthe arengae (TA TW2) was found to be most effective against all tested bacterial and fungal pathogens. Maximum zone of inhibition $(32 \mathrm{~mm})$ was obtained with Diaporthe arengae (TA TW2) extract against $S$. aureus and $B$. subtilis. However, $P$. aerugenosa, $S$. abony and $P$. vulgaris did not show zone of inhibition against the extract of TA BA 2 and TA TW 1. The Diaporthe arengae (TA TW2) extract also showed excellent antifungal activity. All the test fungi were found sensitive with the maximum zone of inhibition $(28 \pm 0.32$ $\mathrm{mm}$ ) was recorded in $C$. albicans. The inhibition zones were found greater than reference drug (Streptomycin and Fluconazole). The results indicate that bioactive principles having antibacterial and antifungal activity are present in the culture filtrate of the endophytic isolates.
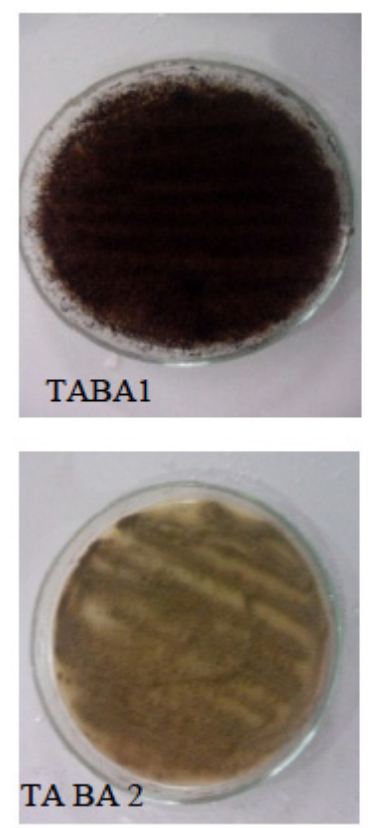
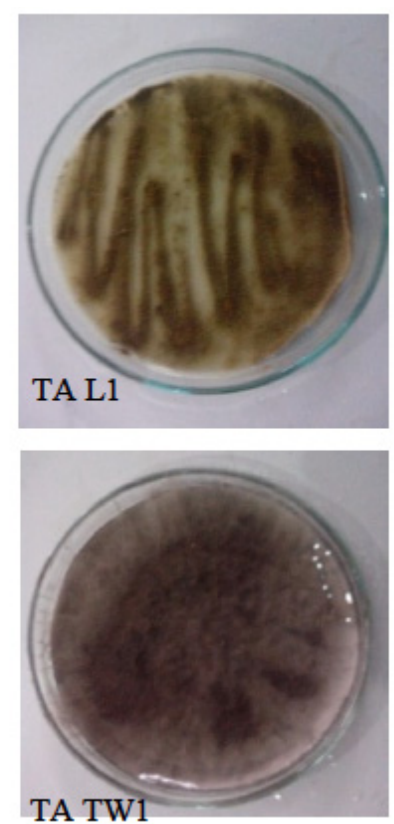
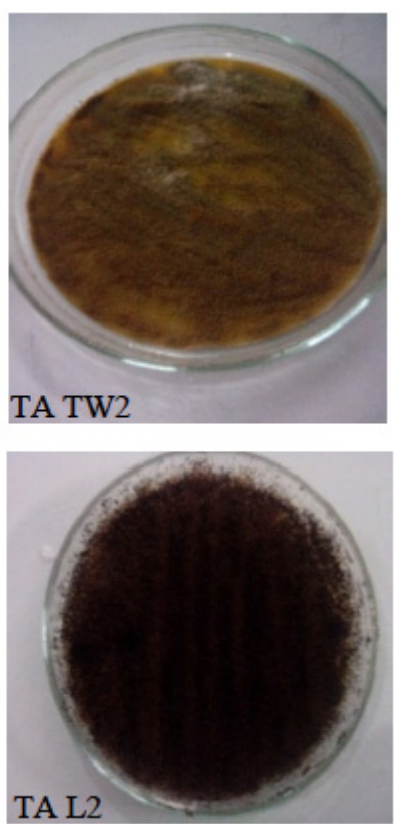

Figure 1: Isolated fungal endophytes from different aerial parts of $T$. arjuna. 


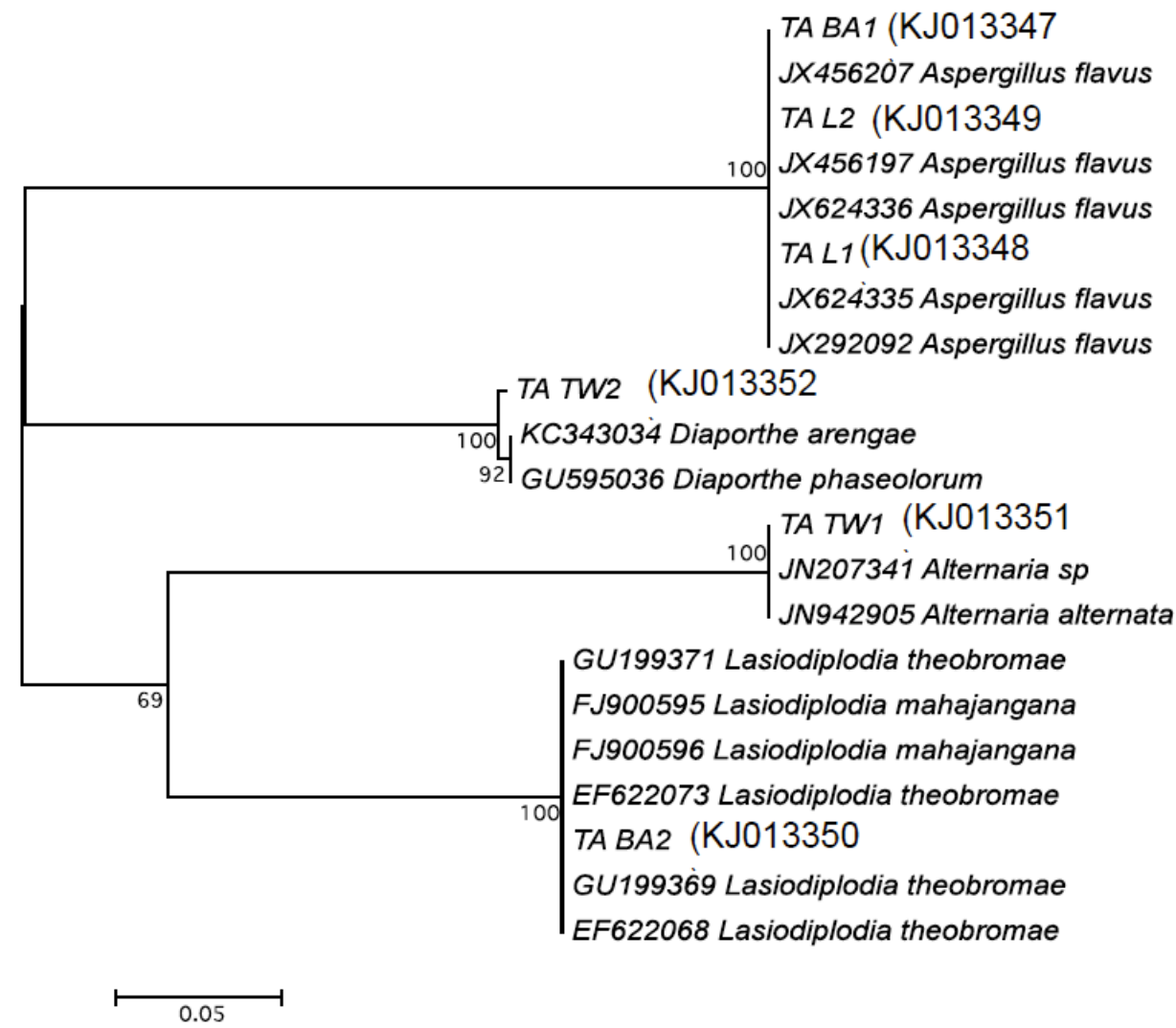

Figure 2: Phylogenetic relationship between isolated endophytes and those from GenBank, based on ITS region using Neighbor-joining method.
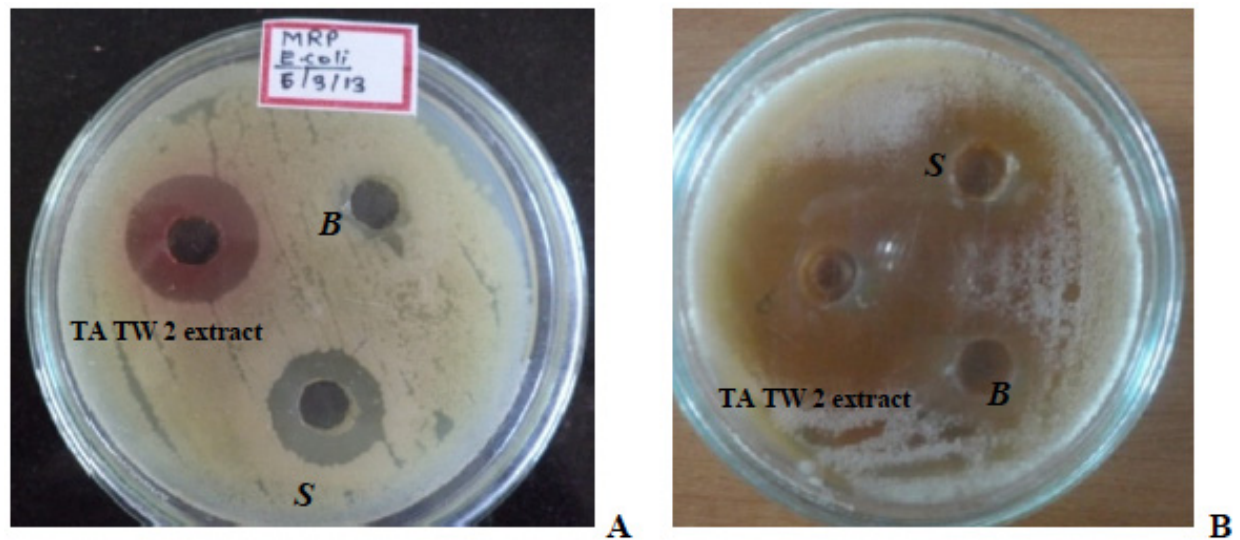

Figure 3: Antimicrobial activity of the test extracts (TA TW 2), standard (S) and solvent blank (B) against $E$. coli $($ A) and Candida albicans (B).

\section{Antioxidant Activity}

The partially purified fermentation extracts of the isolated endophytes and standard (ascorbic acid) were tested for scavenging effect by DPPH method. The comparative results of DPPH scavenging activity of different endophytic isolates and standard (ascorbic acid) are depicted in Figure 4. The extracts of all isolates showed varying levels of scavenging effect. The percent scavenging effect was found to be maximum (69.56\%) with isolate TATW 2 followed by TAL1 $(68.91 \%)$ as compared to standard (68.79).

The results of hydroxyl radical scavenging activity of the endophytic isolates are shown in Figure 5. The results indicate that $\mathrm{OH}^{-}$radical scavenging effect of the isolate TATW2 was the best among all six isolates and were comparable to standard (ascorbic acid). The extracts of other isolates (TABA1 and TABA2) also showed significant $\mathrm{OH}^{-}$radical scavenging activity. 
Table 1: Antibacterial and Antifungal Activity of the Extracts of the Six Endophytic Fungi

\begin{tabular}{|c|c|c|c|c|c|c|c|}
\hline \multicolumn{8}{|c|}{ Zone of inhibition (mm) } \\
\hline Pathogens & $\begin{array}{l}\text { A. flavus } \\
\text { (TA L-1) }\end{array}$ & $\begin{array}{l}\text { A. flavus } \\
\text { (TA L-2) }\end{array}$ & $\begin{array}{l}\text { A. flavus } \\
\text { (TA BA-1) }\end{array}$ & $\begin{array}{c}L . \\
\text { theobromae } \\
\text { (TABA-2) }\end{array}$ & $\begin{array}{l}\text { A. alternata } \\
\text { (TATW-1) }\end{array}$ & $\begin{array}{c}D . \\
\text { arengae } \\
\text { (TATW-2) }\end{array}$ & $\begin{array}{c}\text { Standard } \\
\text { (Streptomycin/Fluconazol) }\end{array}$ \\
\hline E. coli & $30 \pm 0.21$ & - & $20 \pm 0.18$ & - & $30 \pm 0.22$ & $26 \pm 0.23$ & $19 \pm 0.32$ \\
\hline S. aureus & $25 \pm 0.22$ & $12 \pm 0.21$ & $15 \pm 0.18$ & - & $16 \pm 0.18$ & $32 \pm 0.21$ & $22 \pm 0.22$ \\
\hline B. subtilis & $32 \pm 0.20$ & $15 \pm 0.18$ & $22 \pm 0.22$ & $20 \pm 0.18$ & $22 \pm 0.29$ & $32 \pm 0.18$ & $26 \pm 0.18$ \\
\hline P. vulgaris & $26 \pm 0.31$ & $18 \pm 0.21$ & - & - & - & $25 \pm 0.32$ & $16 \pm 0.22$ \\
\hline$P$. aeruginosa & $25 \pm 0.31$ & - & $20 \pm 0.18$ & - & - & $28 \pm 0.18$ & $16 \pm 0.24$ \\
\hline S. abony & $28 \pm 0.32$ & - & $16 \pm 0.22$ & - & - & $22 \pm 0.31$ & $19 \pm 0.32$ \\
\hline A. niger & $20 \pm 0.32$ & - & $15 \pm 0.18$ & $18 \pm 0.21$ & $17 \pm 0.21$ & $26 \pm 0.25$ & $20 \pm 0.18$ \\
\hline A. terreus & - & $20 \pm 0.21$ & -- & - & - & $27 \pm 0.18$ & $23 \pm 0.22$ \\
\hline PenicilliumSpp. & $25 \pm 0.32$ & $15 \pm 0.18$ & $20 \pm 0.22$ & - & - & $22 \pm 0.32$ & $19 \pm 0.22$ \\
\hline C. albicans & $22 \pm 0.21$ & - & - & - & $16 \pm 0.18$ & $28 \pm 0.32$ & $25 \pm 0.26$ \\
\hline
\end{tabular}

Results obtained are mean \pm SD of three parallel experiments (- Negative/ No inhibition zone).

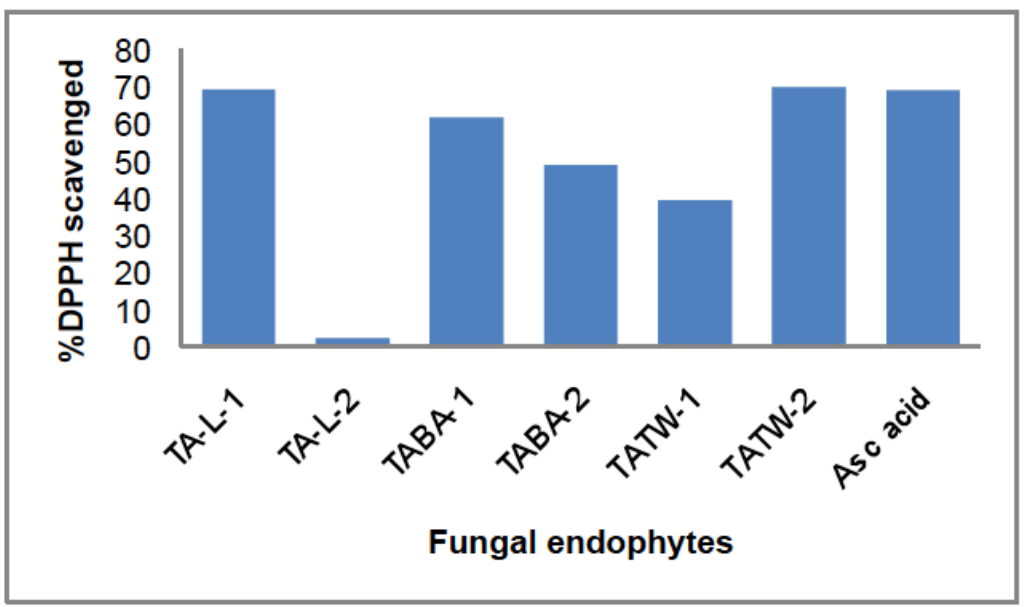

Figure 4: DPPH scavenging activity of isolated endophytes.

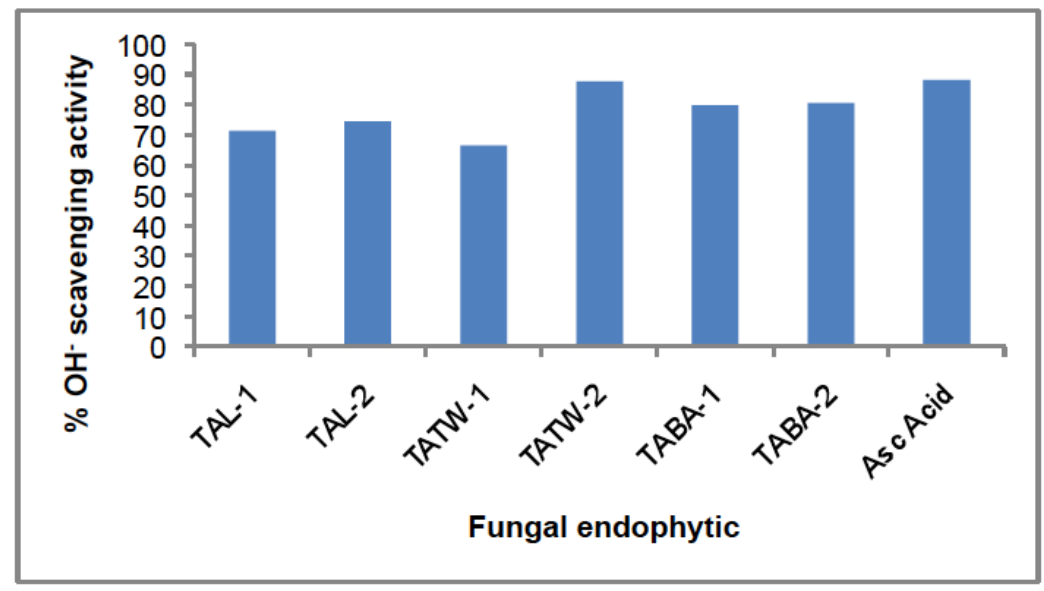

Figure 5: $\mathrm{OH}^{-}$radical scavenging activity of isolated endophytes. 
Table 2: Percent Inhibition of Hemolysis by Extracts of Isolated Endophytes

\begin{tabular}{|c|c|c|c|c|c|c|c|}
\hline \multirow{2}{*}{$\begin{array}{c}\text { Concentration } \\
(\mathbf{m g} / \mathbf{m l})\end{array}$} & \multicolumn{7}{|c|}{$\%$ hemolysis } \\
\cline { 2 - 8 } & lbuprofen & TA L-1 & TA L-2 & TABA-1 & TABA-2 & TATW-1 & TATW-2 \\
\hline \hline 0.2 & $66.05 \pm 0.96$ & $83.67 \pm 1.33$ & $97.7 \pm 0.93$ & $91.68 \pm 0.78$ & $77.45 \pm 1.08$ & $97.00 \pm 0.97$ & $65.68 \pm 0.97$ \\
\hline 0.4 & $37.48 \pm 0.70$ & $41.60 \pm 0.59$ & $82.41 \pm 0.63$ & $81.11 \pm 0.86$ & $86.27 \pm 0.67$ & $75.49 \pm 0.89$ & $35.29 \pm 0.86$ \\
\hline 0.6 & $34.55 \pm 0.54$ & $34.58 \pm 0.97$ & $66.44 \pm 0.49$ & $80.02 \pm 0.93$ & $67.64 \pm 0.78$ & $73.52 \pm 0.99$ & $34.41 \pm 1.02$ \\
\hline 0.8 & $20.20 \pm 0.83$ & $29.52 \pm 0.49$ & $65.47 \pm 2.48$ & $61.00 \pm 1.55$ & $65.91 \pm 0.67$ & $72.00 \pm 0.78$ & $27.22 \pm 0.99$ \\
\hline 1.0 & $16.74 \pm 1.38$ & $35.92 \pm 1.05$ & $63.37 \pm 1.80$ & $61.44 \pm 1.09$ & $67.62 \pm 0.89$ & $87.55 \pm 0.99$ & $17.15 \pm 0.85$ \\
\hline
\end{tabular}

Results obtained are mean \pm SD of three parallel measurements.

The reactive oxygen species (ROS) and the free radicals play an important role in degenerative conditions such as ageing, cancer and inflammation. The metabolites of plant and microbial origin have recently been of great interest as natural antioxidants. The study demonstrated that fermentation extract of TATW2 has antioxidant activity and it was found to be better than the standard ascorbic acid.

\section{Anti-Inflammatory Activity}

The anti-inflammatory activity of the extracts was measured in terms of percent inhibition of RBC hemolysis and the results are summarized in Table 2.

The TATW 2 extract at the concentration of $1.0 \mathrm{mg} / \mathrm{ml}$ significantly protected the lysis of the human RBCs. The TATW 2 extract produced $82.85 \%$ inhibition of hemolysis of RBCs as compared to $83.89 \%$ produced by standard drug (Ibuprofen). The results reveal the strong membrane stabilizing activity of the fermented extract. Furthermore, it was noted that the extract showed a dose dependent protection of RBCs over all the concentration ranges. Several studies have demonstrated that natural compounds of plant and microbial origin possess ability to facilitate the stability of the biological membranes under various stress conditions [20, 23].

\section{Spectroscopic and Chromatographic Characterization of Bioactive Metabolite}

Based on the results of bioactivity studies, the extract of TA TW2 was chosen for partial characterization of bioactive metabolite(s) in it. Preliminary screening of the extract of TA TW2 showed strong positive test for terpenoids (Figure 6A). In TLC of the extract, of the mobile phases tried, best resolution was obtained with Chloroform: Ethyl acetate $(7: 3 \mathrm{v} / \mathrm{v})$. A well resolved band could be seen at $R_{f} 0.42$ under both long UV (365 nm) and in visible light after derivatising it with $5 \% \mathrm{H}_{2} \mathrm{SO}_{4}$ (Figure $6 \mathrm{~B}$ and $\mathbf{C}$ ). The band at $\mathrm{R}_{\mathrm{f}} 0.42$ showed two distinct peaks, at 215and $350 \mathrm{~nm}$, when scanned between 200 to $700 \mathrm{~nm}$ (Figure 6D). Based on these results, we conclude that the major band in the fermentative extract of strain TA TW2 could be a terpenoid which will need further characterization.

Flavonoids and phenolics of plant origin were proved to be potent anti-oxidants and free radical scavengers and several studies have demonstrated the antioxidant activities of flavonoids and phenolic compounds from endophytic fungi [22]. However, the reports on anti-oxidant and membrane stabilizing activities of terpenoids from endophytic fungi are relatively few.

The genetic origin of fungal bioactive metabolite production has been speculated to have arisen by horizontal gene transfer from host plant to its endophytes [2]. However, very little documentation is available for gene transfer from a higher plant to an endophyte. Endophytic fungi are increasingly recognized as sources of novel bioactive compounds and secondary metabolites which offer an enormous potential for exploitation in medicinal, agriculture and industrial uses [24, 25].

\section{CONCLUSION}

On the basis of these results, it can be concluded that the Terminalia arjuna harbors different endophytic fungi in leaf, bark and twigs tissues. The endophytic isolate TATW 2 produced metabolite, believed to be a terpenoid, which has antimicrobial and antioxidant activities. The crude extract of the isolate was capable of preventing the RBC hemolysis as well. The bioactive principle of the isolate could be regarded as natural source of membrane stabilizer and is capable of providing alternative remedy for inflammatory disorders. 

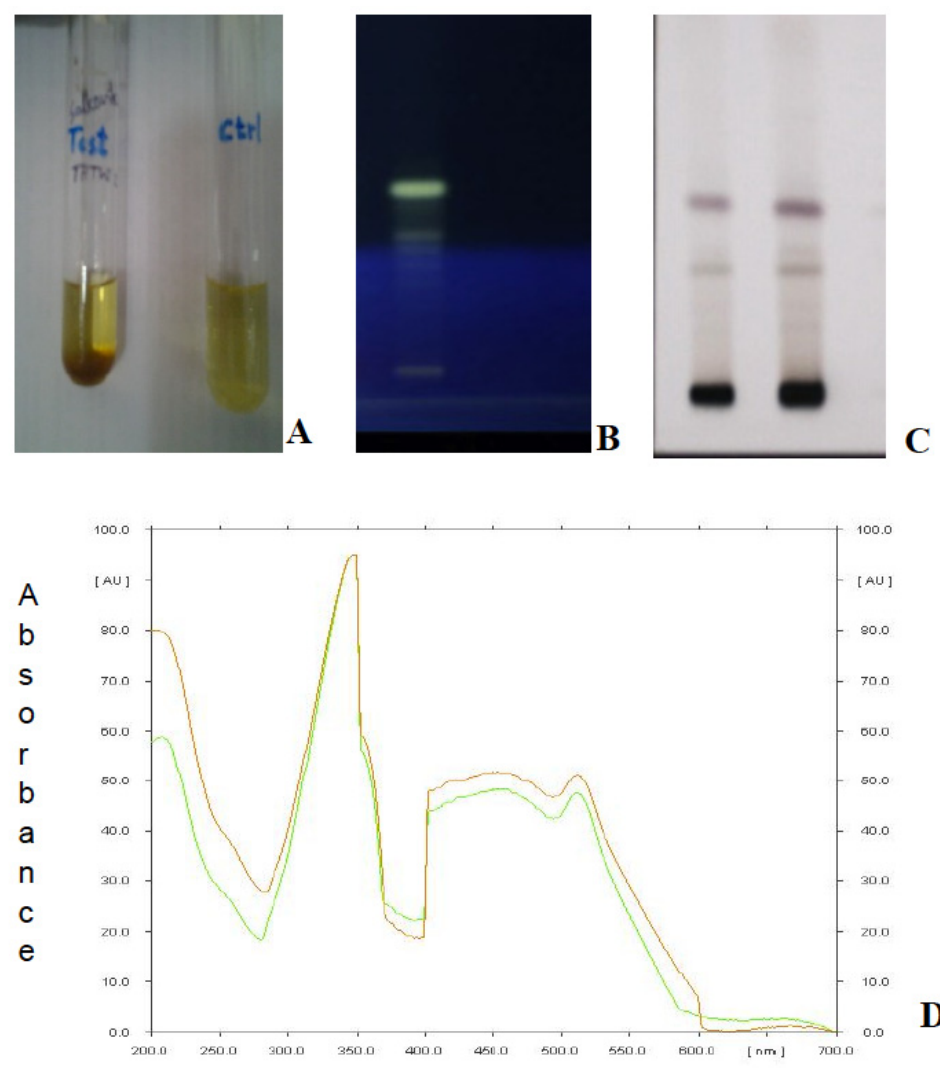

Wavelength

Figure 6: Chemical profile of partially purified extract of TA TW2. (A) Salkowaski test showing reddish brown colored ring at the bottom indicating presence of terpenoids. (B) TLC profile under UV light showing fluorescence at 365nm. (C) TLC profile of the extract showing characteristic brown to violet color bands after derivatisation with $5 \% \mathrm{H}_{2} \mathrm{SO}_{4}$. (D) Absorption spectra of TLC eluted band of $R_{f} 0.42 \pm 0.02$.

\section{ACKNOWLEDGEMENT}

The authors (MPP and RHP) are thankful to SERB, DST, New Delhi, India for providing financial assistance in the form of fast track grant.

\section{REFERENCES}

[1] Bacon C, White J, Microbial Endophytes, Marcel Dekker, Inc. New York. Basel 2000.

[2] Strobel and Daisy. Bioprospecting for microbial endophytes and Their Natural Products. Microbiol Mole Biol Rev 2003; 67:491-502.

http://dx.doi.org/10.1128/MMBR.67.4.491-502.2003

[3] Radu and Kqueen. Preliminary screening of endophytic fungi from medicinal plants in Malaysia for antimicrobial and antitumor activity. M J Med Sci 2002;9: 23-33.

[4] Wang F, Jiao R, Cheng A, Tan S and Song Y. Antimicrobial potentials of endophytic fungi residing in Quercus variabilis and brefeldin A obtained from Cladosporium sp. World $\mathrm{J}$ Microbiol Biotechnol 2007; 23:79-83. http://dx.doi.org/10.1007/s11274-006-9195-4

[5] Chen P, Ozcan M, and Harnly J. Chromatographic fingerprint analysis for evaluation of Ginkgo biloba products. Anal Bioanal Chem 2007; 389:251-61. http://dx.doi.org/10.1021/jf800488x
[6] Purohit A, Maikhuri R, Rao K and Nautiyal S. Impact of bark removal on survival of Taxus baccataL. (Himalayan yew) in Nanda Devi Biosphere Reserve, Garwhal Himalaya, India. Current Sci 2001; 81: 586-90. http://dx.doi.org/10.1007/s12088-010-0056-3

[7] Patil M, Patil R and Maheshwari V. A novel and sensitive Agar Plug Assay for screening of asparginase producing endophytic fungi from Aegle marmelos. Acta Biolo Scz 2012; 56: 1-3.

[8] Yuan J, Jian N, Bing YAN Xu Dong Z.Taxol-producing Fungi: A New Approach to Industrial Production of Taxol. Chin J Biotechnol 2006; 2: 1-6.

[9] Gond, S, Verma V, Kumar A, Kumar V and Kharwar R. Study of endophytic fungal community from different parts of Aegle marmelos Correae (Rutaceae) from Varanasi (India) World J Microbiol Biotechnol 2007; 23: 1371-5. http://dx.doi.org/10.1007/s11274-007-9375-x

[10] Gangadevi V and Muthumary J Taxol, an anticancer drug produced by an endophytic fungus Bartaliniarobillardoides Tassi, isolated from a medicinal plant, Aegle marmelos Correa ex Roxb. W J Microbiol Biotechnol 2008; 24: 717724. http://dx.doi.org/10.1007/s11274-007-9530-4

[11] Anonymous. The Wealth of India. Council of Scientific and Industrial Research (CSIR), New Delhi 1999.

[12] Dwivedi S, Udupa N. Terminalia arjuna: Pharmacognosy, Phytochemistry, Pharmacology and clinical use. A review. Fitoterapia1989; 60: 413-20. 
[13] Patil R and Maheshwari V. Hypolipidemic effect of Terminalia arjuna (L) in experimentally induced hypercholesterolemic rats. Acta Biol Szd. 2011; 55: 2.

[14] Arnold A, Mayard Z, Gilberk G, Coley P and Kursar T. Are tropical fungal endophytes hyperdiverse? Ecol Lett 2000; 3: 267-74.

http://dx.doi.org/10.1046/j.1461-0248.2000.00159.x

[15] Raper K and Fennell D. The genus Aspergillus. Baltimore, Maryland, USA: Williams and willkins: 1965; 1-686.

[16] Wu Z, Wang T, Huang W and Qu Y. A simplified method for chromosome DNA preparation from filamentous fungi. Mycosystema 2001; 20: 575-7. http://dx.doi.org/10.1111/j.1472-765X.2010.02867.x

[17] Harbone J. Phytochemical methods: a guide to modern techniques of plant analysis. Chapman and Hall Limited, London 1980.

[18] Shimada K, Fujikawe K, Yahara K, Nakamura T. Antioxidant properties of Xanthan on the auto oxidation of soybean oil in cyclodextrin emulsion. J Agri Food Chem 1992; 945-8. http://dx.doi.org/10.1021/jf00018a005

[19] Smirnoff $N$ and Cumbes $Q$. Hydroxyl radical scavenging activity of compatible solutes. Phytochemistry 1989; 28: 1057-60.

http://dx.doi.org/10.1016/0031-9422(89)80182-7
[20] Oyedapo O, Akinpelu B, Akinwunmi K, Adeyinka M and Sipeolu F. RBC stabilizing potentials of extracts of Lantana camara and its fractions. Int J Plant Physiol Biochem 2010; 2: 46-51.

[21] Rana B, Singh U, Taneja D. Antifungal activity and kinetics of inhibition by essential oil isolated from leaves of Aegle marmelos. J Ethnopharmacol 1997; 57: 29-34. http://dx.doi.org/10.1016/S0378-8741(97)00044-5

[22] Qiu M, Xie R-S, Shi $Y$, Zhang $H$, Chen, HM. Isolation and identification of two flavonoid-producing endophytic fungi from Ginkgo biloba L. Ann Microbiol 2010; 60: 143-50. http://dx.doi.org/10.1007/s13213-010-0016-5

[23] Hess S, Milloning R. In "Inflammation, Mechanism and Control", Lepow, L.H and Wards, P.A., Eds, Academic Press, New-York, 1972; 1- 72.

[24] Tan R and Zou W. Endophytes: a rich source of functional metabolites. Nat Prod Rep 2001; 18; 448-59. http://dx.doi.org/10.1039/B1009180

[25] Zhang $H$, Song $Y$ and Tan R. Biology and chemistry of endophytes. Nat Prod Rep 2006; 23: 753-71. http://dx.doi.org/10.1039/b609472b

(c) 2014 Patil et al.; Licensee Lifescience Global.

This is an open access article licensed under the terms of the Creative Commons Attribution Non-Commercial License (http://creativecommons.org/licenses/by-nc/3.0/) which permits unrestricted, non-commercial use, distribution and reproduction in any medium, provided the work is properly cited. 